\title{
Optimization of Agricultural Waste Hydrolysis using Nepenthes mirabilis Digestive Fluids
}

\author{
Rachel K. Kanda ${ }^{\mathrm{a}, \mathrm{b}}$, Justine O. Angadam ${ }^{\mathrm{b}}$, Seteno K. O. Ntwampe ${ }^{\mathrm{a}, \mathrm{b}}$ and Boredi S. Chidi ${ }^{\mathrm{b}}$
}

\begin{abstract}
Waste management in the 21 st century has been motivated by the rapid population growth and industrialization, climate change, generation of different waste, scarcity of resources and stringent environmental legislation. Waste management in South Africa in particular, is motivated by the need to develop green technologies for energy production and ensure compliance with national imperatives. It has been ascertained that the agricultural industry in South Africa largely contributes to the nation's total wastean immense threat for surface and underground water bodies. This paper places a focus on a waste management strategy that utilizes the organic fraction of agro-waste (referred to as agro-waste/ agricultural waste/ lignocellulosic waste) as a raw material for biofuel generation using a cocktail of enzymes naturally produced by the Nepenthes mirabilis plant (pitcher plant) coupled with other pretreatment techniques. It highlights a proposed optimization approach for the technique using cofactors that naturally enhance the activities of previously isolated $N$. mirabilis enzymes.
\end{abstract}

Keywords-Biovalorisation, Co-factors, Delignification, Lignocellulosic biomass.

\section{INTRODUCTION}

Agricultural waste varies in physical, chemical, and microbial composition depending on the source. The greatest threats agricultural waste accumulation poses are landfill dumping, underground, surface water and soil sources contamination by virtue of their pollution potential. The generated agro-waste consists of different carbohydrate sources in varying amounts with great bio-valorisation potential. For example, citrus fruits for the beverage industry reached a worldwide production of $68 \times 106$ tonnes (t) in 2012. Approximately $30-40 \%$ of the fruits accumulate as citrus waste in the form of seeds and peels with a high cellulose and low lignin content respectively and are sold has dried feed. Another example includes the potential use of palm oil residues that amounts to $70 \%$ of the crop yield for cellulosic fibres [1].

Irrespective of the source type, the abundant lignin, cellulose and hemicellulose in agricultural waste material remain a great carbohydrate source for bio-valorisation. Considering that

Manuscript received October 14 2019. This work was supported in part by Cape Peninsula University of Technology (CPUT) under URF RK16 and Bioresource Engineering Research Group (BioERG) under RK45.

${ }^{\mathrm{a}}$ Department of Chemical Engineering, Faculty of Engineering and the Built Environment, Cape Peninsula University of Technology, P.O. Box 1906, Bellville, 7535, South Africa.

${ }^{\mathrm{b}}$ Bioresource Research Group, Cape Peninsula University of Technology, P.O. Box 652, Cape Town, 8000 South Africa, agriculture is a common practice worldwide, it is thus safe to positively predict the sustainable production of biofuel from these crop residues [2].

\section{A. The Need for Bio-valorisation of Agro-wastes}

For decades, incineration has been the auto-remedy for agricultural waste management. The challenges with this waste strategy range from the illogical amount of energy required for incineration to the unacceptable amount of toxins released into the environment. With the stringent environmental protection legislations established, comes an even greater need for more eco-friendly strategies to agricultural waste management. When agro-waste undergoes pretreatment, lignin, the macromolecule responsible for the rigidity and recalcitrance of the plant is destabilised. This exposes the plant's hemicellulose and cellulose to hydrolysis that can further be utilised for biogas and bio-alcohol production. For example Oksman et al. [3] and Tsukamoto et al. [4] reported a suitable and profitable pathway to using beverage industry by-products by transforming fermentable sugars into bioethanol and cellulose nanocrsytals. Dlangamandla et al. [5] also reported the transformation of agricultural waste hydrolysates into butanol and ethanol. This integrated technology cuts down the amount of waste generated from agricultural activities while achieving a sizeable benefit for industries and reducing production costs [2].

\section{OVERVIEW}

\section{A. Agricultural Waste}

Agricultural waste is described as any residue obtained from first processing of farming products such as crops, meat, vegetables, fruits, and poultry. It encompasses both organic and inorganic wastes generated form the agricultural industry, i.e. livestock breeding, forestry, farming, grazing land, etc. These wastes accumulate in the form of slurries or sludge, solid state, and liquids rich in pathogens, organic and inorganic chemicals. Agricultural wastes can be characterised on the basis of the activities that generate them. A brief summary is given in Table I.

\section{B. Physico-chemical Properties of Some Agro-wastes}

Plant cell walls are composed of mainly cellulose, hemicellulose, and lignin. Agricultural lignocellulosic material contains approximately $40-50 \%$ cellulose, $20-30 \%$ hemicellulose, and 10-25\% lignin with a great potential for biofuel generation [6]. The relative proportions of these polysaccharides (Table II) in a plant is an important factor to consider for pretreatment, i.e. a lignin-rich plant will resist 
saccharification by virtue of its increased recalcitrance, while a cellulose-rich plant will require minimum energy for hydrolysis. Furthermore, choosing the ideal lignocellulosic biomass for subsequent bio-energy production is equally dependent on the ratio content of these polysaccharides [7].

TABLE I: A FEW AGRICULTURAL ACTIVITIES AND THEIR RELATED WASTES [8].

\begin{tabular}{|c|c|c|c|c|}
\hline \multicolumn{2}{|l|}{ Agricultural activity } & \multicolumn{3}{|c|}{ Type of wastes } \\
\hline \multicolumn{2}{|l|}{ Crop production and harvest } & \multicolumn{3}{|c|}{ Straw, stover } \\
\hline \multicolumn{2}{|c|}{ Fruit and vegetable processing } & \multicolumn{3}{|c|}{$\begin{array}{l}\text { Biological sludge, trimmings, peels, } \\
\text { leaves, stems, soil, seeds and pits }\end{array}$} \\
\hline \multicolumn{2}{|l|}{ Sugar processing } & \multicolumn{3}{|c|}{ Biological sludge, pulp, lime mud } \\
\hline \multicolumn{2}{|l|}{ Animal production } & \multicolumn{3}{|c|}{$\begin{array}{l}\text { Blood, bones, feather, litter, } \\
\text { manures, liquid effluents }\end{array}$} \\
\hline \multicolumn{2}{|l|}{ Dairy product processing } & \multicolumn{3}{|c|}{ Biological sludge } \\
\hline \multicolumn{2}{|l|}{ Rice production } & \multicolumn{3}{|c|}{ Bran, straw, hull } \\
\hline \multicolumn{2}{|l|}{ Leather tanning } & \multicolumn{3}{|c|}{$\begin{array}{l}\text { Fleshings, hair, raw and tanned } \\
\text { trimmings, lime and chrome sludge, } \\
\text { grease }\end{array}$} \\
\hline \multicolumn{5}{|c|}{$\begin{array}{l}\text { TABLE II: CHEMICAL COMPOSITION OF SOME AGRO-WASTE USED IN } \\
\text { ADDED PRODUCT GENERATION (ANGADAM ET AL., 2019) } \\
\end{array}$} \\
\hline "Lignocellulosic material & \multicolumn{2}{|c|}{$\begin{array}{l}\text { Cellulose } \\
(\%)\end{array}$} & $\begin{array}{l}\text { Hemicellulose } \\
(\%)\end{array}$ & $\begin{array}{l}\text { Lignin } \\
(\%)\end{array}$ \\
\hline Biomass in general & \multicolumn{2}{|c|}{$35-50$} & $20-35$ & $10-30$ \\
\hline Different grass mixes & \multicolumn{2}{|c|}{$28.8-36.0$} & $17.9-24.7$ & $13.4-17.5$ \\
\hline Wheat straw & \multicolumn{2}{|c|}{40.2} & 38.8 & 17.0 \\
\hline Grasses & \multicolumn{2}{|c|}{$25-40$} & $25-50$ & $10-30$ \\
\hline Corn stover & \multicolumn{2}{|c|}{$38-40$} & 28 & $7-21$ \\
\hline
\end{tabular}

\section{MATERIALS, METHODS AND ASSOCIATED LITERATURE}

\section{A. Pretreatment of Agricultural Waste}

The natural tendency of lignocellulosic biomass to resist microbial and/or enzymatic digestion is termed recalcitrance. For this study, to achieve saccharification of cellulose, the biomass will be exposed to physical, chemical, and thermal pre-treatment. The pre-treatment methods render the tightly lignin-bound cellulose and hemicellulose accessible for hydrolysis [9]. Physical pre-treatment methods include grinding to reduce particle size and increase surface area for the lignocellulosic biomass [10] while hot water pre-treatment (HWP) techniques allows rapid delignification of biomass, eliminates the need for invasive chemicals usage, and is independent of the biomass particle size [11].

Irrespective of the aforementioned pros, Angadam et al [11] affirm that Dilute Acid pre-treatment (DAP: $0.4 \%-2 \% \mathrm{H}_{2} \mathrm{SO}_{4}$ at $160-220^{\circ} \mathrm{C}$ ) is advantageous over HWP as the latter produces a higher yield of fermentable sugars as compared to DAP. However, the authors report that both techniques result in the formation of inhibitory compounds at different conditions, e.g. HWP result in the production of furfural and phenolic compounds at elevated temperatures that impound on downstream processes, while DAP may result in the formation of soluble lignin from xylose degradation.

Both DAP and HWP serve as entry processes for Cellulases Pre-treatment (CP). Cellulases consist of a combination of endoglucanases, cellobiohydrolases (exoglucanases), and $\beta$-glucosidases [12]. Angadam et al [11] observed that pre-treating lignocellulosic biomass with mild acid prior to cellulases digestion resulted in an increase of $33 \%$ total readily dissolvable sugars as compared to the untreated biomass.
However, in spite of this impressive effect of dilute acid pre-treatment, the author reports formation of toxicants when subsequently treated with cellulases as opposed to sole-cellulases pre-treatment.

\section{B. Nepenthes mirabilis: A Plausible Green Solution}

Tropical pitcher plants, commonly known as Nepenthes spp., is the name given to the group of carnivorous plants belonging to the family Nepenthaceae. Naturally occurring in many tropical regions of South Eastern Asia, these plants have evolved physiological mechanisms that allow them to prey on insects and other small animals to thrive in their naturally low-nutrient habitats. These survival mechanisms are in the form of engulfing organs into which preys are trapped and utilised as primary food sources.

Carnivorous plants have captured the undeterred interest of scientists in the field of botany by virtue of their evolutionary defense and survival mechanisms, intriguing structure, drought tolerance, and nutritional strategy [13]. An example of its survival mechanism is the symbiotic relationship between the carnivorous plant and its endophytes present within the monkey cup that confer the plant survival properties. These endophytes include several fungal and bacterial species that asymptotically colonise the plant organs and are established as the natural microbial flora of this preventing secondary succession.

\section{Physico-chemical Composition of the N. mirabilis Digestive Fluids}

Dlangamandla et al [5] describes the physico-chemical properties of the pitcher plant's digestive fluids. To determine electrolyte strength and the ability of the digestive fluids to facilitate oxidation reactions, conductivity and redox potential of the fluids were measured using a multi-parameter meter. These characteristics are listed in Table III.

TABLE III: PHYSICO-CHEMICAL COMPOSITION OF THE N. MIRABILIS DIGESTIVE

\begin{tabular}{ll}
\multicolumn{2}{c}{ FLuIDS [5]. } \\
\hline \hline Characteristic/Parameter & Results \\
\hline $\mathrm{pH}$ & $1.80-2.2$ \\
Specific gravity & $0.67-0.82$ \\
Redox potential & $510-526 \mathrm{mV}$ \\
Conductivity & $3.5-5.89 \mathrm{mS} / \mathrm{cm}$ \\
\hline \hline
\end{tabular}

\section{Enzymes of the Digestive Fluid}

The pitcher fluid contains digestive enzymes that extract nutrients from entrapped insects. Table IV shows a non-exhaustive list of prominent isolated enzymes of the carnivorous plant from different literature sources and basic substrates.

TABLE IV: ENZYMES IN NEPENTHES MIRABILIS PLANTS' DigESTIVE FLUIDS [5,

\begin{tabular}{cc} 
& $11]$ \\
\hline \hline Enzyme & Substrates \\
\hline Chitinases & Chitin \\
Phosphatases & Phosphomonoester \\
Proteases & Proteins \\
Nucleases & Nucleic Acids \\
Peroxidases & $\mathrm{H}_{2} \mathrm{O}_{2}$ \\
Glucanases & Glucans \\
Lipases & Lipids \\
\hline \hline
\end{tabular}




\section{RESULTS AND DISCUSSION}

\section{A. The use of Cofactors for Optimisation of Agro-waste Hydrolysis}

Countless literature studies encourage pre-treatment of agricultural waste to facilitate and optimize downstream processes. An amalgamated pre-treatment technology ultimately results in higher product yield and simultaneously, form inhibitory compounds. It thus becomes paramount to introduce fundamental concepts that present possible solutions to ensuring product yield contain little to no inhibitory compounds that may halt important catalytic reactions. The use of a stream of co-factors that will bind to the digestive fluids' enzymes may not only result in an increase in product formation, but also in a decrease in furfurals and phenolic compounds.

Wilkie et al [14] reported that anaerobic digestion of Napier grass supplemented with nitrogen and phosphorus decreased methane $\left(\mathrm{CH}_{4}\right)$ production and increased volatile fatty acids (VFAs) production. Moreover, the author also reports a $40 \%$ increase and a significant decrease in $\mathrm{CH}_{4}$ and VFAs respectively when a stream of molybdenum, sulphate, selenium, cobalt and nickel were added daily. Using the fundamental knowledge of the relationship between co-factors and co-enzymes, it is plausible to hypothesize positive results in terms of optimization. Moreover, the daunting task will lay in determining appropriate nutrients/cofactors for isolated enzymes.

\section{CONCLUSION}

The use of a stream of nutrients for agro-waste hydrolysis using the carnivorous plant's digestive fluids is a promising and innovative approach to waste management process optimization. To date, no study has directly reported this and thus challenges pertaining to process parameters such as optimum ratio of enzyme: cofactor quantities and even appropriate nutrients for isolated enzymes may prove a daunting task.

\section{ACKNOWLEDGMENT}

The authors would like to extend their gratitude to the Cape Peninsula University of Technology for availing funds for the study and conference attendance.

\section{REFERENCES}

[1] Ferrer, A., Quintana, E., Filpponen, I., Solala, I., Vidal, T., Rodríguez, A., Laine, J., Rojas, O.J., 2012. Effect of residual lignin and heteropolysaccharides in nanofibrillar cellulose and nanopaper from wood fibers. Cellulose 19, 2179-2193. https://doi.org/10.1007/s10570-012-9788-Z

[2] García-Torreiro, M., López-Abelairas, M., Lu-Chau, T.A. and Lema, J.M., 2016. Fungal pretreatment of agricultural residues for bioethanol production. Industrial Crops and Products, 89, pp.486-492. https://doi.org/10.1016/j.indcrop.2016.05.036

[3] Oksman, K., Etang, J.A., Mathew, A.P. and Jonoobi, M., 2011. Cellulose nanowhiskers separated from a bio-residue from wood bioethanol production. Biomass and Bioenergy, 35(1), pp.146-152. https://doi.org/10.1016/j.biombioe.2010.08.021
[4] Tsukamoto, J., Durán, N. and Tasic, L., 2013. Nanocellulose and bioethanol production from orange waste using isolated microorganisms. Journal of the Brazilian Chemical Society, 24(9), pp.1537-1543. https://doi.org/10.5935/0103-5053.20130195

[5] Dlangamandla, N., Ntwampe, S. K. O., Angadam, J. O., Itoba-Tombo, E. F., Chidi, B. S. \& Mekuto, L. 2019. Integrated hydrolysis of mixed agro-waste for a second generation biorefinery using Nepenthes mirabilis pod digestive fluids. Processes, 7 (2): 64. https://doi.org/10.3390/pr7020064

[6] Anwar, Z., Gulfraz, M. and Irshad, M., 2014. Agro-industrial lignocellulosic biomass a key to unlock the future bio-energy: a brief review. Journal of Radiation Research and Applied Sciences, 7(2), pp.163-173. https://doi.org/10.1016/j.jrras.2014.02.003

[7] Fenila, F. and Shastri, Y., 2016. Optimal control of enzymatic hydrolysis of lignocellulosic biomass. Resource-Efficient Technologies, 2, pp.S96-S104.

https://doi.org/10.1016/j.reffit.2016.11.006

[8] Li, Y., Park, S.Y. and Zhu, J., 2011. Solid-state anaerobic digestion for methane production from organic waste. Renewable and Sustainable Energy Reviews, 15(1), pp.821-826.

https://doi.org/10.1016/j.rser.2010.07.042

[9] Sannigrahi, P., Ragauskas, A.J. and Tuskan, G.A., 2010. Poplar as a feedstock for biofuels: a review of compositional characteristics. Biofuels, Bioproducts and Biorefining, 4(2), pp.209-226. https://doi.org/10.1002/bbb.206

[10] Gunaseelan, V.N., 1997. Anaerobic digestion of biomass for methane production: a review. Biomass and Bioenergy, 13(1-2), pp.83-114. https://doi.org/10.1016/S0961-9534(97)00020-2

[11] Angadam, J., Ntwampe, S. \& Dlangamandla, N. ^2018. Phanerochaete chrysosporium supported biovalorisation of grape pomace for hyper reducible sugar extraction. Proceedings of the 10th International Conference on Advances in Science, Engineering, Technology \& Healthcare (ASETH-18), Cape Town, South Africa, 2018. 19-20.

[12] Kumar, R., Singh, S. and Singh, O.V., 2008. Bioconversion of lignocellulosic biomass: biochemical and molecular perspectives. Journal of Industrial Microbiology \& Biotechnology, 35(5), pp.377-391. https://doi.org/10.1007/s10295-008-0327-8

[13] Adlassnig, W., Peroutka, M. \& Lendl, T. 2011. Traps of carnivorous pitcher plants as a habitat: composition of the fluid, biodiversity and mutualistic activities. Annals of Botany, 107 (2): 181-194. https://doi.org/10.1093/aob/mcq238

[14] Wilkie, A., Goto, M., Bordeaux, F.M. and Smith, P.H., 1986. Enhancement of anaerobic methanogenesis from napiergrass by addition of micronutrients. Biomass, 11(2), pp.135-146. https://doi.org/10.1016/0144-4565(86)90043-0

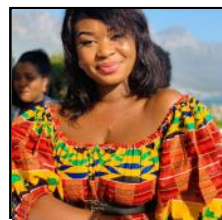

Rachel K. Kanda, originally of the Democratic Republic of the Congo, was born $6^{\text {th }}$ March 1995. She is currently enrolled for a Master of Engineering in Chemical Engineering having graduated with a National Diploma in Biotechnology cum laude and a BTech degree in Biomedical Technology (Biotechnology) cum laude at the Cape Peninsula University of Technology. She received a Merck Best student for Biotechnology Award for her academic exploits in Biotechnology in 2017. 